\title{
A new species of the sharpshooter genus Cardioscarta (Hemiptera: Cicadellidae) from Bolivia and Peru
}

\author{
Rodney Ramiro Cavichioli* \& Gabriel Mejdalani²
}

\author{
${ }^{1}$ Departamento de Zoologia, Setor de Ciências Biológicas, Universidade Federal do Paraná. Caixa Postal 19020, \\ 81531-980 Curitiba, PR, Brazil. \\ ${ }^{2}$ Departamento de Entomologia, Museu Nacional, Universidade Federal do Rio de Janeiro. Quinta da Boa Vista, \\ São Cristóvão, 20940-040 Rio de Janeiro, RJ, Brazil.E-mail: mejdalan@acd.ufrj.br \\ *Corresponding author. E-mail: cavich@ufpr.br
}

\begin{abstract}
The South American sharpshooter genus Cardioscarta Melichar, 1932 comprises six species. In this paper we describe and illustrate $C$. splendida sp. nov. based on a specimen from Bolivia (male holotype deposited in DZUP). The new species can be recognized by the orange ground color with five transverse dark brown stripes on dorsum (one on crown and four on forewings), and by the aedeagus with two pairs of dorsal processes on the basal apodemes and a single process at the apex of the shaft. A female from Peru is tentatively assigned to the new species and is also described, since it has the same color pattern as the holotype. An updated key to males and females of all known species of the genus is also given.
\end{abstract}

KEY WORDS. Cicadellinae, Cicadellini, leafhopper, morphology, taxonomy.

Cardioscarta Melichar, 1932 currently includes six species of colorful sharpshooters: C. albigutta (Walker, 1851), C. electa Melichar, 1932, C. flavifrons (Signoret, 1853), C. quadrifasciata (Linnaeus, 1758) (type species), C. sponsa Melichar, 1932, and C. vernicosa (Le Peletier \& Serville, 1825). This genus, which is recorded from Colombia and the Guianas to southern Brazil and Bolivia, is considered related to Poeciloscarta Stål, 1869 and Janastana Young, 1977 (Young 1977). Cardioscarta can be distinguished from Poeciloscarta and Janastana, as well as from the remaining Neotropical genera of Cicadellini, by the following combination of characters: (1) ocelli located on an imaginary line between anterior eye angles; (2) thorax with pronotal width greater than transocular width of head; (3) pronotal surface without rugae; (4) male pygofer strongly produced posteriorly and without processes; (5) subgenital plates not abruptly narrowed anteapically; and (6) aedeagus with processes basally or more apically on shaft.

Here we describe a new Cardioscarta species based on a male from Bolivia. A female from Peru with the same color pattern as the holotype is also tentatively assigned to the new species and is described. However, this female is not included in the type series of the new species. An updated key to the species of the genus, adapted from Young (1977), is provided.

\section{MATERIAL AND METHODS}

Techniques for preparation of genital structures follow OMAn (1949) and Cavichioli \& TakiYa (2012) for the male, and
Mejdalani (1998) for the female. Dissected parts were stored in small vials with glycerin and attached to the pins, below the specimens, as suggested by Young \& BeIRne (1958). Temporary slides of the ovipositor valvulae, with glycerin, were mounted. Photographs were taken with digital cameras attached to a stereomicroscope or to a light microscope. In most cases, CombineZP, free software developed by Alan Hadley, was employed to produce a single focus photograph from a stack of images. The specimens studied are deposited in the Coleção de Entomologia Pe. Jesus S. Moure, Departamento de Zoologia, Setor de Ciências Biológicas, Universidade Federal do Paraná (DZUP, Curitiba, Brazil).

The descriptive terminology adopted herein follows mainly Young (1977), except for the facial areas of the head (Hamilton 1981, Mejdalani 1993, 1998), leg chaetotaxy (Rakitov 1998, Dietrich 2005), and female genitalia (SNOdgrass 1933, Nielson 1965, Hill 1970). Use of the term gonoplac (= third ovipositor valvula) and the names of the sculptured areas of the first ovipositor valvulae follow MEJDALANI (1998).

About 75 Neotropical described species of the Cicadellinae are currently considered of uncertain identity or position (see Young 1977). Over the last 25 years, our research group has assembled data on these species through the examination of type specimens and careful study of original descriptions, redescriptions, photographs, drawings, and geographical distribution. These species of uncertain identity or position were ruled out before erecting the new species-group name proposed here. 


\section{TAXONOMY}

\section{Cardioscarta splendida sp. nov.}

Figs. 1-19

urn:Isid:zoobank.org:act:BFC90912-8092-4A76-AA7D-7397642381C7

Length: male holotype $12.4 \mathrm{~mm}$, female $13.3 \mathrm{~mm}$.

Male holotype (Bolivia): Head (Figs. 1-2). Well produced anteriorly, median length of crown approximately $3 / 5$ of interocular width and $2 / 5$ of transocular width; anterior margin broadly rounded in dorsal view; without carina at transition from crown to face; ocelli located on imaginary line between anterior eye angles, each closer to adjacent anterior eye angle than to median line of crown; disk of crown without sculpturing or setae; posterior portion of crown elevated between ocelli; frontogenal sutures extending onto crown and attaining ocelli; antennal ledges, in dorsal view, not protuberant and, in lateral view, with anterior margin oblique and convex; frons convex, muscle impressions distinct, inferior third with slight median protuberance; epistomal suture incomplete; clypeus slightly produced, in profile with its upper portion continuing contour of frons and lower portion more nearly horizontal, apex convex.

Thorax (Figs. 1-2). Pronotum with width greater than transocular width of head, lateral margins convergent anteriorly, posterior margin approximately rectilinear; disk without sculpturing or pubescence. Mesonotum with scutellum not transversely striate. Forewings coriaceous, without sculpturing; venation distinct, slightly elevated; with three closed anteapical cells and four apical cells, base of fourth more proximal than base of third; membrane including apical cells, distal portions of anteapical cells and of costal cell delimited by R1 and R2+3; without anteapical plexus of veins. Hind legs with femoral setal formula 2.1.1; length of first tarsomere greater than combined length of two more distal tarsomeres and with two parallel rows of small setae on plantar surface.

Color (Figs. 1-2). Background color of body orange. Crown with broad, posterior dark brown transverse stripe; dorsal portion of pronotum entirely dark brown; mesonotum entirely dark brown except for orange apex. Forewings with four dark brown, complete transverse stripes: one at base continuous with pro- and mesonotum color, one on basal third, one on apical third, and one on apical portion (the last two connected to each other at first apical cell). Face and thorax with dark brown marks as follows: posterior portion of genae and maxillary plates, proepisterna, most of lateral lobes of pronotum, and (at mesothorax) anepisterna, katepisterna, and epimera. Legs mostly orange; posterior tibiae with contrasting dark brown macrosetae (AD, PD, and AV rows).

Genitalia. Pygofer (Fig. 3), in lateral view, well produced posteriorly, with apex angulate, without processes; macrosetae distributed mostly along ventroapical third, with group of smaller setae located between macrosetae and pygofer margin. Subgenital plates (Figs. 3-4), in ventral view, triangular, narrowing gradually toward apex, extending to apical third of pygofer; not fused to each other basally; with uniseriate macrosetae located along outer margin; dorsal surface with group of small setae on basal third. Connective (Fig. 5), in dorsal view, T-shaped, with arms and stalk elongate; stalk articulated with aedeagal preatrium. Styles (Fig. 5), in dorsal view, extending posteriorly beyond apex of connective; apophysis long, slender, and curved, without preapical lobe, apex obtuse and with slight outer projection. Aedeagus (Figs. 6-8) symmetrical, complex; preatrium well developed; basal apodemes, in lateral view, with pairs of ventral and dorsal projections, the latter forming two pairs of processes: dorsal processes (SBP) shorter, crossing each other above aedeagal shaft, ventral processes (LBP) longer, sinuous, extending beyond apex of shaft (ASH); the latter with a strong spiniform process at apex; gonoduct directed dorsally, gonopore located at a lobulate projection of shaft.

Female (based on additional specimen from Peru). Genitalia. Sternite VII (Figs. 9-10), in ventral view, strongly produced posteriorly; median portion of posterior half with pair of elevated carinae that converge posteriorly and form median carina that reaches posterior margin; the latter with pair of lateral emarginations, forming median triangular lobe. "Internal" sternite VIII (Fig. 11), in dorsal view, with distinct, sclerotized anterior arc (ASC) connected to three pairs of posterior sclerites (OSC, MSC, and ISC), the inner pair of sclerites located adjacent to each other, forming central ellipsoid orifice. Pygofer (Fig. 10), in lateral view, well produced posteriorly; posterior margin narrowly rounded; macrosetae distributed apically and ventroapically. First valvifer, in lateral view, subrectangular. First valvulae (Fig. 12), in ventral view, only slightly expanded basally; in lateral view, with basal half curved and distal half approximately rectilinear, apex acute; dorsal sculptured area (Figs. 13-14) extending from basal portion to apex of blade, formed by scalelike processes arranged in oblique lines at median and apical portions, basal portion with more horizontal linear processes; ventral sculptured area (Fig. 15) restricted to apical portion of blade, formed by scale-like processes; ventral interlocking device located at basiventral half of blade. Second valvulae (Fig. 16), in lateral view, expanded beyond basal curvature; apex obtuse; preapical prominence small but distinct; dorsal margin convex and with about 50 continuous subtriangular teeth (Figs. 17-19), most of them with small ascending portion and elongate descending portion; denticles distributed on teeth and on ventral and dorsal apical portions of blade; ventral dentate apical portion longer than dorsal portion. Gonoplacs, in lateral view, abruptly expanded at median third and then narrowing gradually toward obtuse apex. Color as in male holotype; abdomen with sternite VII and pygofer (Figs. 9-10) dark brown to black.

Material examined (DZUP). Male holotype: "Bolivia.। Tounga [Yungas] de la Paz. \1903-188." Additional specimen, female: "Peru, Cuzco, $19 \mathrm{~km} \backslash \mathrm{a}$ NE de Marcapata, \Capire, $1270 \mathrm{~m}, \backslash 13.424^{\circ} \mathrm{S}, 70.905^{\circ} \mathrm{W} \backslash 31 . v i i i .2012$, G. Melo". The wings of the holotype are damaged apically, especially those of the left side. The head of the female is slightly damaged; it is not perfect- 

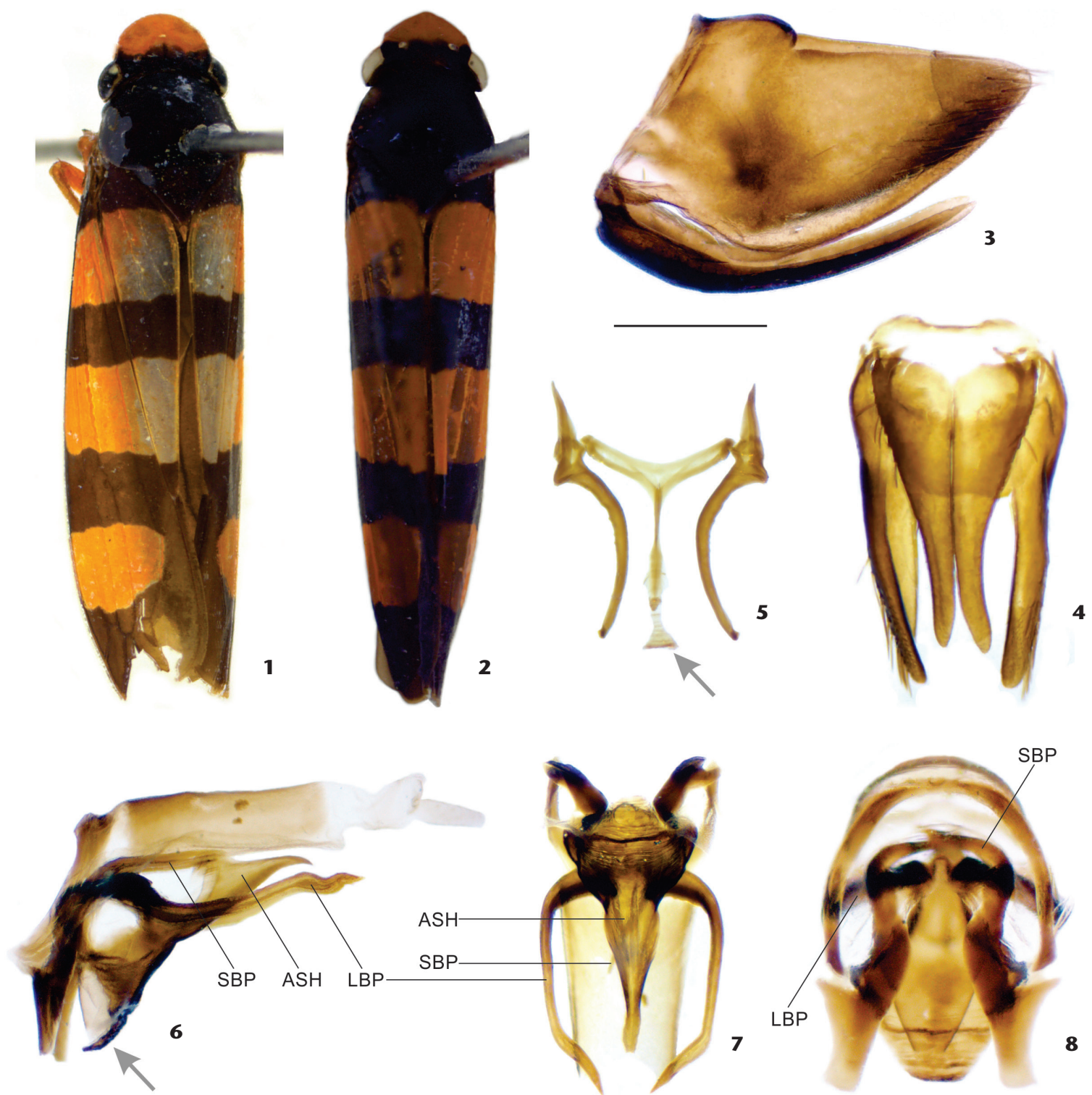

Figures 1-8. Cardioscarta splendida sp. nov.: (1) habitus of the male holotype from Bolivia, length $12.4 \mathrm{~mm}$; (2) habitus of a female from Peru (see remarks), length $13.3 \mathrm{~mm}$; (3-8) male genitalia: (3) pygofer and subgenital plate, lateral view (with scale bar); (4) valve, subgenital plates, and pygofer, ventral view; (5) connective and styles, dorsal view (a detached portion of the aedeagal preatrium is at the apex of the connective stalk, arrowed); (6-8) aedeagus and anal tube: (6) in lateral, (7) ventral, and (8) anterior views (damaged preatrium is arrowed in Fig. 6). Abbreviations: (ASH) aedeagal shaft; (LBP) longer basal process; (SBP) shorter basal process. Scale bar: $1 \mathrm{~mm}$.

ly connected to the thorax and thus is not in the correct position; its anterior margin also appears to be abnormally angulated.

Etymology. The specific name, splendida, refers to the beautiful color pattern of the body in dorsal and lateral views.

Remarks. Although the male holotype and the female specimen are from different countries (Bolivia and Peru, respectively), we consider them as belonging to the same species, due to their remarkably similar color pattern (Figs. 1-2). At the current state of our knowledge, the color pattern appears to vary greatly interspecifically among the Cardioscarta species (see digital images of the body in dorsal view in WiLSON et al. 2009 and the key provided below). However, we acknowledge that this association is tentative and may change when more specimens become available, and for this reason we have chosen not to include the female in the type series. Both male and female were apparently collected in the Andean Yungas. 

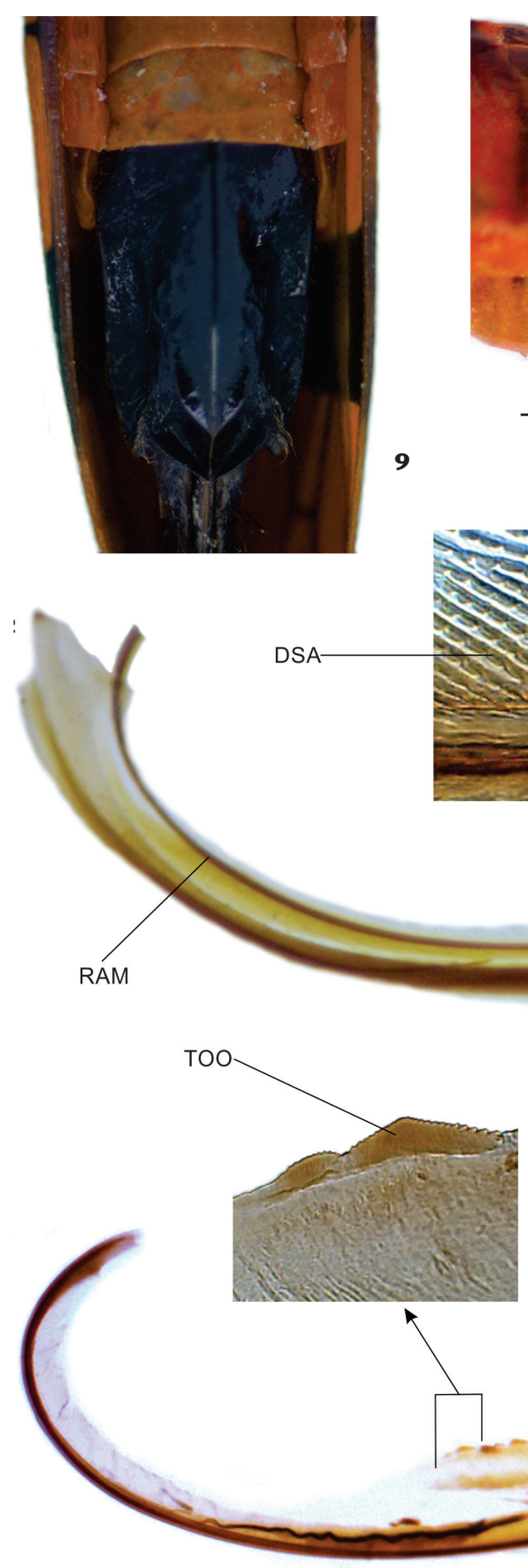

17
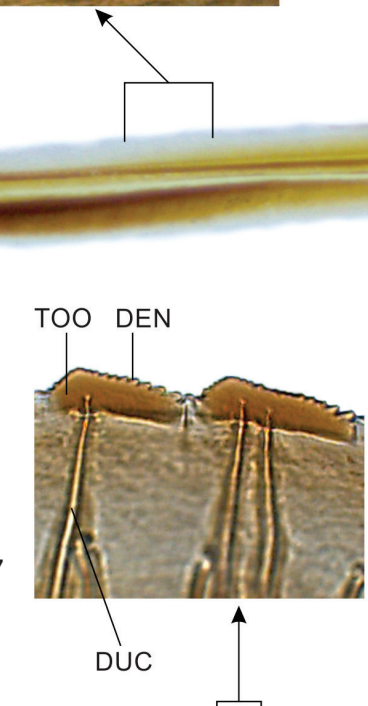

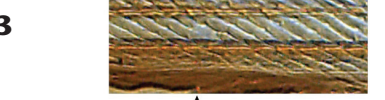

14

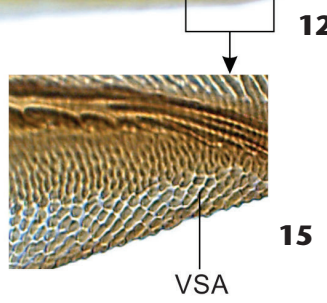

18

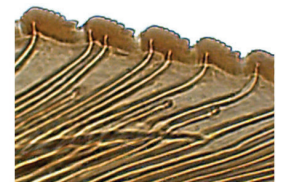

19

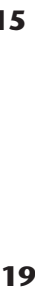

Figures 9-19. Cardioscarta splendida sp. nov., female from Peru (see remarks): (9-10) apical portion of abdomen: (9) ventral and (10) lateral view (with scale bar); (11) "internal" sternite VIII, dorsal view; (12-15) valvula I: (12) lateral view; (13) median portion of dorsal sculptured area; (14) apical portion of dorsal sculptured area; (15) ventral sculptured area; (16-19) valvula II: (16) lateral view; (17) teeth at basal portion; (18) teeth at median portion; (19) teeth at apical portion. Abbreviations: (ASC) anterior (arc-like) sclerite; (DEN) denticle; (DSA) dorsal sculptured area; (DUC) duct; (ISC) inner sclerite; (MSC) median sclerite; (OSC) outer sclerite; (PPR) preapical prominence; (RAM) ramus; (TOO) tooth; (VSA) ventral sculptured area. Scale bar: $1 \mathrm{~mm}$. 
The color pattern of C. splendida sp. nov. is similar to that of C. electa, a species known from Ecuador and Bolivia (McKamey 2007). Both species share five broad, transverse dark brown stripes (one on crown and four on forewings). However, C. electa has a pair of large pale orange marks on the pronotum (Melichar 1932, Young 1977, Wilson et al. 2009) that is not observed in the new species. In addition, the aedeagus of $C$. electa has a single pair of elongate basal processes, plus a pair of smaller processes on the distal half of the shaft (Young 1977), whereas the aedeagus of $C$. splendida has two pairs of basidorsal processes (Figs. 6-7). The new species has also a spiniform process at the apex of the aedeagal shaft, a feature that is not present in C. electa. The unique shape and processes of the aedeagus of C. splendida also distinguish it from the remaining species of the genus. We provide below a key to males and females of the seven known species of Cardioscarta, including information on their distribution (from McKamey 2007).

\section{Key to species of Cardioscarta (updated from YounG 1977)}

1. Forewings with three or four transverse dark brown to black stripes (Figs. 1-2)

$1^{\prime}$. Forewings without transverse stripes or at most with one transverse dark brown to black stripe at level of apex of clavus.. 4

2. Pronotum with two large pale orange spots narrowly separated medially (Ecuador, Bolivia)..................... C. electa Melichar

2 '. Pronotum without pale spots (Figs. 1-2) .3

3. Forewings with three transverse dark brown to black stripes, none located at base (Colombia, Peru, Guyana, French Guiana, Suriname, Bolivia, Brazil)..C. quadrifasciata (Linnaeus)

3 '. Forewings with four transverse dark brown to black stripes, one located at base (Figs. 1-2) (Peru, Bolivia)

.C. splendida sp. nov.

4. Forewings yellowish-orange with black markings at apex; paraphyses absent (Brazil) C. flavifrons (Signoret)

4 '. Forewings not as above; paraphyses present .5

5. Forewings opaque, black, with white markings (Brazil)......... C. albigutta (Walker)

5'. Forewings yellow or orange with longitudinal dark brown to black markings

6. Forewings with claval suture and commissural margin black (Brazil)..... C. vernicosa (Le Peletier \& Serville) 6 '. Forewings with only a narrow costal black stripe (Brazil)..... ..C. sponsa Melichar

\section{ACKNOWLEDGMENTS}

Research productivity fellowships from Conselho Nacional de Desenvolvimento Científico e Tecnológico (CNPq) are acknowledged (process 305484/2014-1 to RRC and 303627/20140 to GM). This study was supported in part by Fundação de
Amparo à Pesquisa do Estado do Rio de Janeiro (FAPERJ, process E-26/111.181/2011 to Nelson Ferreira-Jr - Departamento de Zoologia, Instituto de Biologia, Universidade Federal do Rio de Janeiro, UFRJ). This paper is the contribution number 1930 of the Departamento de Zoologia, Universidade Federal do Paraná. The manuscript benefited from the useful comments of Daniela M. Takiya and Ângelo P. Pinto (UFRJ).

\section{LITERATURE CITED}

Cavichioli RR, TakiYa DM (2012) Description of a new species of Wolfniana and new records of Rotigonalia (Hemiptera: Cicadellidae: Cicadellinae) from the state of Amazonas, Brazil. Zoologia 29(1): 85-88. doi: 10.1590/S1984-46702012000100011

Dietrich CH (2005) Keys to the families of Cicadomorpha and subfamilies and tribes of Cicadellidae (Hemiptera: Auchenorrhyncha). Florida Entomologist 88(4): 502-517. doi: 10.1653/0015-4040(2005)88[502:KTTFOC]2.0.CO;2

Hamilton KGA (1981) Morphology and evolution of the rhynchotan head (Insecta: Hemiptera, Homoptera). Canadian Entomologist 113(11): 953-974. doi: 10.4039/Ent113953-11

HiLL BG (1970) Comparative morphological study of selected higher categories of leafhoppers (Homoptera: Cicadellidae). Ann Arbor, University Microfilms, XI+187p.

McKamey SH (2007) Taxonomic catalogue of the leafhoppers (Membracoidea). Part 1. Cicadellinae. Memoirs of the American Entomological Institute 78: 1-394.

Mejdalani G (1993) Morfologia da cabeça de Versigonalia ruficauda (Walker, 1851), com notas sobre a terminologia (Homoptera, Cicadellidae, Cicadellinae). Revista Brasileira de Entomologia 37(2): 279-288.

Mejdalani G (1998) Morfologia externa dos Cicadellinae (Homoptera, Cicadellidae): comparação entre Versigonalia ruficauda (Walker) (Cicadellini) e Tretogonia cribrata Melichar (Proconiini), com notas sobre outras espécies e análise da terminologia. Revista Brasileira de Zoologia 15(2): 451-544. doi: 10.1590/ S0101-81751998000200015

Melichar L (1931) [1932] Monographie der Cicadellinen. IV. Annales Historico-Naturales Musei Nationalis Hungarici 27: 287-328.

Nielson MW (1965) A revision of the genus Cuerna (Homoptera, Cicadellidae). Technical Bulletin of the United States Department of Agriculture 1318: 1-48.

OMAN PW (1949) The Nearctic leafhoppers (Homoptera: Cicadellidae). A generic classification and check list. Memoirs of the Entomological Society of Washington 3: 1-253.

RAKITOV RA (1998) On differentiation of cicadellid leg chaetotaxy (Homoptera: Auchenorrhyncha: Membracoidea). Russian Entomological Journal 6(3-4): 7-27.

SNODGRASS RE (1933) Morphology of the insect abdomen. Part II. The genital ducts and the ovipositor. Smithsonian Miscellaneous Collections 89: 1-148.

Wilson MR, Turner J, McKamey SH (2009) Sharpshooter leafhoppers of the world (Hemiptera: Cicadellidae subfamily Ci- 
cadellinae). Available online at http://naturalhistory.museumwales.ac.uk/sharpshooters/home.php [Accessed: 11/06/2015] Young DA (1977) Taxonomic study of the Cicadellinae (Homoptera: Cicadellidae). Part 2. New World Cicadellini and the genus Cicadella. Bulletin of the North Carolina Agricultural

Submitted: 27 July 2015

Received in revised form: 10 December 2015

Accepted: 18 December 2015

Editorial responsibility: Ângelo Parise Pinto
Experiment Station 239: 1-1135.

Young DA, BeIRne BP (1958) A taxonomic revision of the leafhopper genus Flexamia and a new related genus (Homoptera: Cicadellidae). Technical Bulletin of the United States Department of Agriculture 1173: 1-53.

Author contributions: RRC and GM participated equally in the preparation of this article.

Competing interests: The authors have declared that no competing interests exist. 